\title{
Congruence of the composition of Odonata between dry and rainy seasons in the Maranhense Cerrado
}

\author{
Lucas Pereira Moura (iD) ${ }^{a *}$, Sheyla Regina Marques Couceiro (iD) ${ }^{\mathrm{b}}$, Leandro Juen (iD ${ }^{\mathrm{c}}$ and \\ Daniel Silas Veras $\mathbb{1}^{d}$ \\ ${ }^{a}$ Programa de Pós-graduação em Biodiversidade (PPGBEES), Universidade Federal do Oeste do Pará, \\ Laboratório de Ecologia e Taxonomia de Invertebrados Aquáticos, Santarém, Pará, Brazil $;{ }^{b}$ Universidade \\ Federal do Oeste do Pará, Instituto de Ciências e Tecnologia das Águas - ICTA, Laboratório de Ecologia \\ e Taxonomia de Invertebrados Aquáticos, Santarém, Pará, Brazil, ${ }^{c}$ Universidade Federal do Pará. \\ Instituto de Ciências Biológicas. Laboratório de Ecologia e Conservação, Belém, Pará, Brazil; ${ }^{d}$ Instituto \\ Federal do Maranhão, Laboratório de Ecologia de Comunidades, Caxias, Maranhão, Brazil
}

(Received 13 April 2020; final version received 2 June 2020)

\begin{abstract}
Nos riachos tropicais a sazonalidade tem forte influência sobre a heterogeneidade, alterando os recursos disponíveis e ocasionando o carreamento de organismos, substrato e matéria orgânica. Provocando mudanças nas variáveis limnológicas, bem como na composição de espécies. O objetivo de nosso trabalho foi avaliar a congruência de resposta da comunidade de Odonata em duas estações sazonais em riachos da transição entre Cerrado e Caatinga. Foram amostrados 10 riachos afluentes do rio Itapecuru em Caxias, no leste do Maranhão nos meses de julho a dezembro de 2017 (menor precipitação) e em janeiro a junho de 2018 (maior precipitação). Um total de 386 espécimes foram coletados sendo 160 na estação de menor precipitação e 226 para a estação de maior precipitação. Não houve congruência de resposta para a ordem Odonata entre as estações, no entanto, para as subordens separadamente, Zygoptera apresentou alta congruência de imaturo, mas não houve para Anisoptera. Assim, em ambientes que enfrentam um forte estresse hídrico e devido as diferenças ecofisiológicas das subordens, a amostragem de apenas um período sazonal não fornece dados consistentes sobre a composição das espécies (Zygoptera apresentou semelhança na composição entre os dois períodos, mas não para Anisoptera), perdendo informações importantes sobre a diversidade local. Se o foco é a biodiversidade, o uso de subordinados pode estabelecer padrões de diversidade e adaptação entre as estações, tendo em vista as diferenças ecofisiológicas existentes.
\end{abstract}

Palavras-Chave: Sazonalidade; Odonatofauna; similaridade; riachos tropicais

In tropical streams, seasonality has a strong influence on heterogeneity, altering available resources and affecting the carrying of organisms, substrate and organic matter. This causes changes in the limnological variables, as well as in the species composition. The aim of our study was to evaluate the response of the congruence of the Odonata community in two seasons in streams of the transition between Cerrado and Caatinga. Ten tributary streams of the river Itapecuru in Caxias, in eastern of Maranhão, were sampled from July to December 2017 (lowest precipitation) and from January to June 2018 (highest precipitation). A total of 386 specimens were collected, 160 in the season with the lowest precipitation and 226 in the season with the highest precipitation. There was no congruence of response for the order Odonata between the seasons; however, if the suborders are treated separately, Zygoptera presented a high congruence of larvae, but not Anisoptera. Thus, in environments that face strong water stress and due to the ecophysiological differences of the suborders, the sampling of only one seasonal period does not provide consistent data on the species composition (Zygoptera showed similarity in the composition between drought and rainy seasons, but not Anisoptera), losing important information about local diversity. If the focus is on biodiversity, the use of suborders can establish patterns of diversity and adaptation between seasons, in view of the existing ecophysiological differences.

Keywords: seasonality; Anisoptera; Zygoptera; similarity; tropical streams; dragonfly

*Corresponding author. Email: lucas.moura@acad.ifma.edu.br 


\section{Introduction}

The physical and chemical characteristics of tropical streams vary seasonally throughout the year, due to the increase or decrease of precipitation. This climatic seasonality influences the heterogeneity of habitats, the abiotic variables and availability of resources in these systems (Oliveira-Junior, Cabette, Silva-Pinto, \& Juen, 2013; Pereira, Pio, Calor, \& Copatti, 2017; Vaz, Vaz, Pelizari, Biagioni, \& Smith, 2017), significantly affecting the community structure of aquatic organisms (Bartels, Ask, Andersson, Karlsson, \& Giesler, 2018). This variability of the environment acts as a filter, selecting the species with the best ecological strategies for survival and permanence in that ecosystem, shaping the community as a whole (Elosegi \& Pozo, 2016; Rosser \& Pearson, 2018).

Understanding how species respond to the heterogeneity of the natural environment helps in the development of dynamic population models and ecosystem processes (Mendes, OliveiraJunior, Cabette, Batista, \& Juen, 2017; Rosser \& Pearson, 2018). In a continuous flow, this understanding makes it possible to establish monitoring mechanisms that allow assessment of the environmental conditions of streams (Salcedo, 2006; Souza, 2010; Vilas Boas \& Camargo, 2017; Yokoyama, Paciencia, Bispo, Oliveira, \& Bispo, 2012), comparing and differentiating effect of natural and anthropogenic changes (Costa, Branco, \& Bispo, 2014).

Aquatic systems are dynamic and complex and are directly and indirectly influenced by several factors that can act at different scales (Heino et al., 2004; Leps et al., 2015). One of these factors is the precipitation, which interferes in the habitat structure (e.g. width, depth and flow), even in streams whose vegetation on the banks completely covers their course, through the horizontal flow of rain (Pontes, De Lima, Júnior, \& De Azevedo Sadeck, 2017; Veras, Medeiros-França, \& Azêvedo, 2018; Yokoyama et al., 2012). The variation in the volume of water can directly decrease or create new types of mesohabitats by varying the combinations of the characteristics of the substrates (microhabitats) and the surface flows of water (habitats) (Beisel et al., 1998). In addition, constant water spills cause homogenization of the stream substrate, limiting important resources for the maintenance of fauna (e.g. food and micro-habitats). The changes from the increase (rainy season) or reduction (dry season) pluviometric modify the environmental gradients that determine the structure of the communities present in the different micro-habitats (García-Roger et al., 2011; Giam et al., 2017). Due to changes in gradients between seasonal periods, several ecological studies with aquatic macroinvertebrates have comparisons between climatic seasons in order to demonstrate the effects of seasons on the beta diversity of these organisms (Dos Santos Bertoncin, Pinha, Baumgartner, \& Mormul, 2019; Marques \& Del-Claro, 2010; Oliveira \& Frizzas, 2008; Salcedo, 2006), especially from Odonata.

Odonata are important components of aquatic food chains because they are top predators in these ecosystems (Anderson \& Semlitsch, 2016; Pinto, 2016), feeding on other aquatic insects, as well as fry and tadpoles. Furthermore, the fauna of Odonata is widely used in ecological studies of environmental monitoring and evaluation, since many taxa, even at the suborder level, are sensitive to environmental changes (Corbet, 1999; De Marco, Batista, \& Cabette, 2015; Pinto, 2016), with mesohabitats and substrates present in the streams being major predictors of the composition of larvae (Mendes, Benone, \& Juen, 2019; Pires, Siegloch, Hernández, \& Petrucio, 2020) and conditions of the gallery forest being a potential predictor for adults (De Marco et al., 2015; Juen, Oliveira-Junior, Shimano, Mendes, \& Cabette, 2014).

The two suborders of Odonata registered in Brazil, Anisoptera and Zygoptera, have ecophysiological distinctions for adults and larvae (De Marco et al., 2015; Mendes et al., 2019). Anisoptera larvae are larger in size than Zygoptera larvae and tolerate greater environmental variation (greater plasticity) with many generalist species (Mendes et al., 2019). Meanwhile, Zygoptera larvae need complete environmental conditions (Mendes, Cabette, \& Juen, 2015; 
Monteiro-Junior, Couceiro, Hamada, 2013). Thus, throughout evolutionary history, species have developed different ecological strategies that meet the demands provided by variations in the environmental gradient due to the different levels of precipitation (Corbet, Suhling, \& Soendgerath, 2006). Most Anisoptera species have two or more emergences of the larval phase for adults per year (bivoltine or multivoltine) (Reels, 2011), while species of Zygoptera have only one emergence per year, with exceptions, or every two years (univoltine or semivoltine) (Corbet, 1999; Corbet et al., 2006; Purse \& Thompson, 2002).

Considering the environmental variations produced by the changing levels of precipitation, our objective was to evaluate the congruence of response of the Odonata community, considering the two suborders in two seasons with pronounced differences in precipitation in a transition area between Cerrado and Caatinga. The following hypotheses will be tested: (1) there will be differences in richness and abundance for the order and suborders, with rainfall rates modifying the environment, forcing the migration of individuals who need specific conditions; (2) there will be no congruence in the composition of larval Odonata between seasons, since the difference in precipitation rates promotes the modification of mesohabitat and some of the individuals quickly complete their life cycle; (3) when compared separately, we expect a high level of congruence in Zygoptera between periods of drought and rainy season, as they present a longer period of diapause in response to seasonal variations, staying longer in the water to complete their life cycle.

\section{Methodology}

\section{Study area}

The study was carried out in first and third order tributaries of the Itapecuru River, in Caxias, Maranhão (Figure 1). The city of Caxias is located in the eastern region of the state, in an area of the Cerrado-Caatinga ecotone (Reis \& Conceição, 2010). It presents a diversity of phytophysiognomies such as semi-deciduous forests, typical cerrado, fields, gallery forests, as well as anthropized areas such as second-growth forests (capoeira) and babaçu forests (Oliveira, Medeiros, Oliveira, \& Conceição, 2018; Reis \& Conceição, 2010; Veras, Castro, Lustosa, Azevêdo, \& Juen, 2019).

Caxias has a sub-humid to semi-arid climate, with temperatures ranging between $21.2^{\circ} \mathrm{C}$ and $38.3^{\circ} \mathrm{C}$. The rainfall is $1200-1300 \mathrm{~mm}$ per year, with two well-defined climatic seasons, a rainy summer (January to June) and a dry winter (July to December) (Correia-Filho, 2011; Fernandes, Conceição, Costa, \& Paula-Zárate, 2010). For the last three years the average rainfall for the period of least precipitation was $16 \mathrm{~mm}( \pm 16.8)$, while for the period of greatest precipitation it was $227.1 \mathrm{~mm}$ ( \pm 285.4) (Instituto Nacional de Meteorologia (INMET), 2020).

Itapecuru River basin is $52,884 \mathrm{~km}^{2}$ in area. This basin is of paramount importance to the state, as it provides water supply to riverside cities, and is also used in family farming, livestock, fish farming and transportation in the region (De Alcântara, 2004).

\section{Collection, screening and identification of larvae Odonata}

Ten streams were sampled (Table S1) in two seasons: dry (July to December 2017) and rainy (January to June 2018), totaling 20 sample units. In each stream a $50 \mathrm{~m}$ transect was delimited on one of its banks, divided into five sample sections of $10 \mathrm{~m}$ each. Each section was searched with the aid of an aquatic entomological net in $\mathrm{D}$ (rapiché with $1 \mathrm{~mm}$ mesh), sieves and by manual collections of larval Odonata. The available substrates (logs, submerged roots, leaves, stones and 


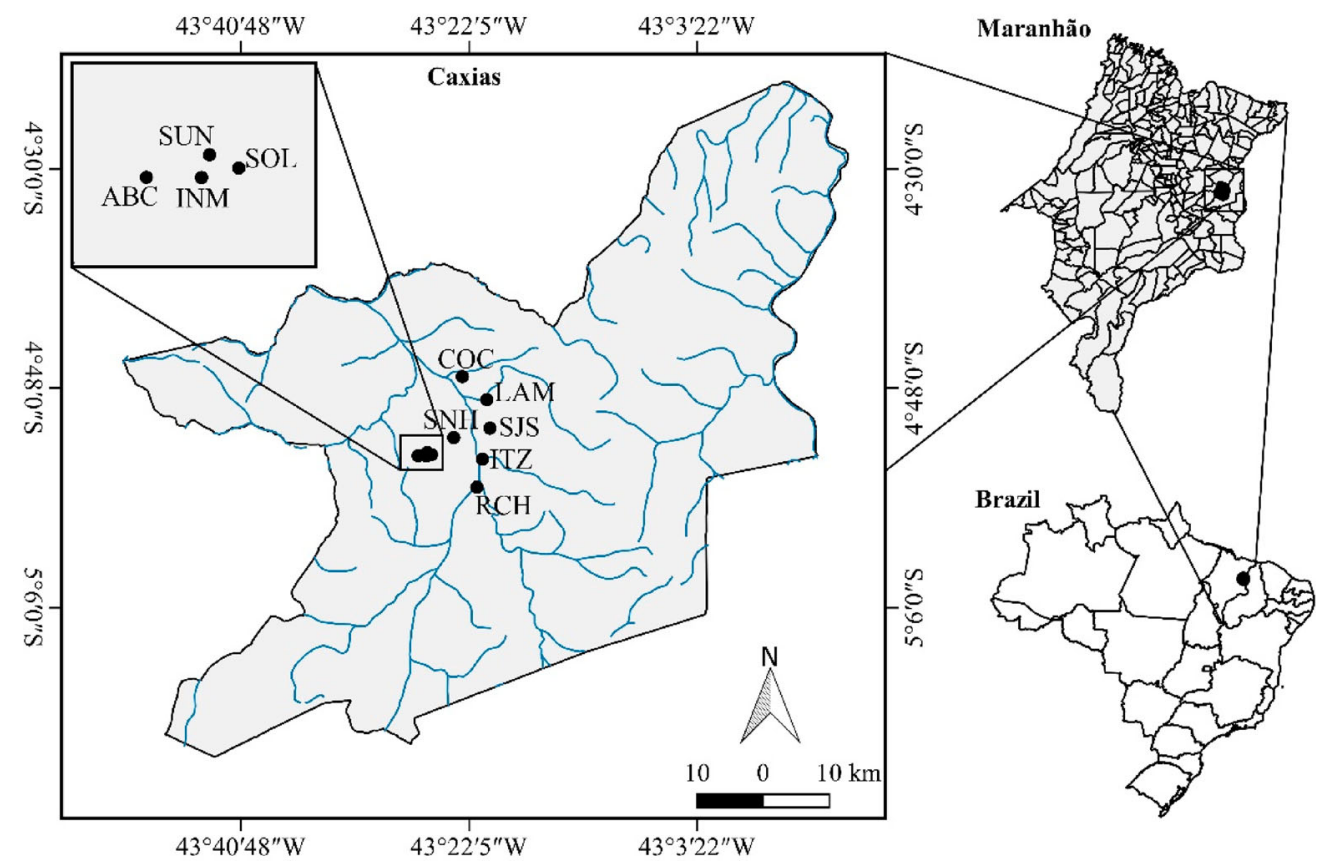

Figure 1. Hydrographic basin of the Itapecuru River in the city of Caxias, Maranhão, Brazil. Streams: Areia Branca (ABC), Cocos (COC), Inhamum (INH), Itapecuruzinho (ITZ), São José (SJS), Lamego (LAM), Riachão RCH), Sanharó (SNH), Soledade (SOL), Sumidouro (SUM).

macrophytes) in each section were sieved and examined three times, following the methodology proposed by Dias-Silva, Cabette, Juen, and De Marco (2010). After collection, Odonata larvae were stored in vials containing $70 \%$ ethanol. To identify the samples, a stereomicroscope was used with taxonomic keys to the genus level (Costa, Azevedo, Ferreira, \& Moura, 2015; Costa \& Oldrini, 2005; Hamada, Nessimian, \& Querino, 2014). Some studies on larvae have already used this taxonomic resolution to produce good results and relationships (e.g. Mendes et al., 2015; Valente-Neto et al., 2016).

\section{Data analysis}

The jackknife first-order non-parametric richness estimator was used to construct the accumulation curve and verify the collection efficiency, as well as to compare the estimated richness between the seasons with the highest and lowest precipitation. This estimator takes into account the rarity of specimens, by randomizing the pseudo-replicates of each stream (Ferreira-Peruquetti \& De Marco Jr, 2002; Mendes et al., 2017). Abundance represented the simple counting of individuals per stream.

Due to ecophysiological differences, we treated the Anisoptera and Zygoptera order and suborders separately. To check if there are differences in abundance and richness between suborders and in each collection period, we performed $t$-tests independent, transforming the data $(\log 10[\mathrm{x}+1])$ so that the assumptions were met.

For composition, six matrices were generated with data of abundance of the taxa transformed by $(\log 10[x+1])$ by climatic season (Odonata, Anisoptera and Zygoptera $\times$ dry season and rainy season). The matrices were reduced by PCoA (principal coordinate analysis) ordering, using the Bray-Curtis distance in order to verify the similarity in the composition of the communities between stations. Then, the data were also analyzed by Procrustes (Procrustean 

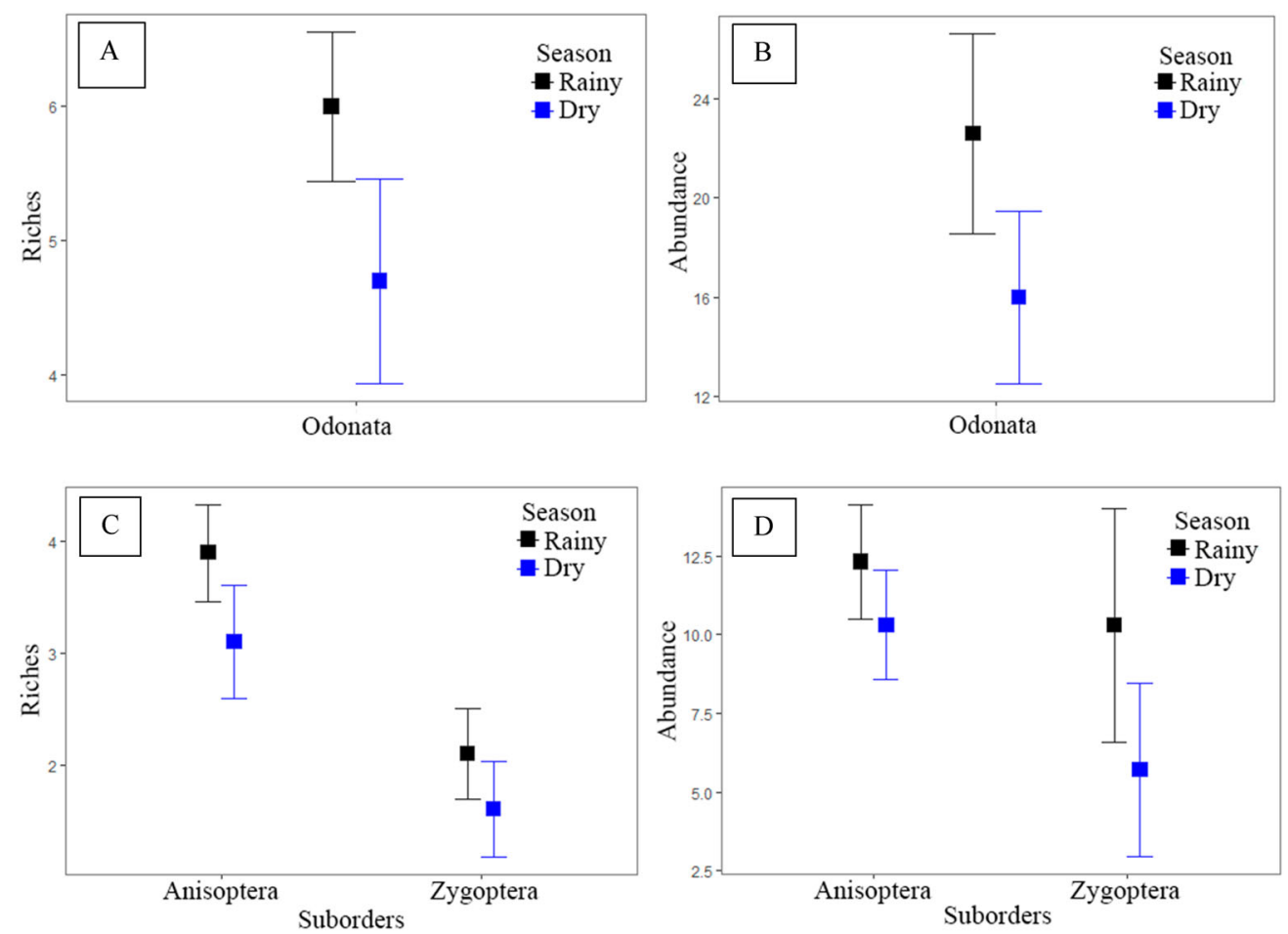

Figure 2. (A) Comparison of richness $(t=-1.378 ; \mathrm{df}=18 ; p=0.185)$ and (B) abundance $(t=-1.244 ; \mathrm{df}=18$; $p=0,230)$ for Odonata larvae between the dry and rainy seasons in Caxias city, Maranhão; (C) comparison of richness (Anisoptera: $t=-1.203$; $\mathrm{df}=18 ; p=0.244$; Zygoptera: $t=-0.847$; $\mathrm{df}=18 ; p=0.407$ ) and (D) abundance (Anisoptera: $t=-0.793$; df $=18 ; p=0.438$; Zygoptera: $t=-1.230$; $\mathrm{df}=18 ; p=0.234$ ) for larvae of the suborders between the dry and rainy seasons in Caxias city, Maranhão.

Randomization Test) (Mendes et al., 2017; Shimano, Cardoso, \& Juen, 2018) determining the significance of the congruence between dry and rainy seasons for Odonata, Anisoptera and Zygoptera.

To perform the statistical tests, the software EstimateS 7 and the statistical environment $\mathrm{R}$ version 1.1.383 with a vegan package (R Development Core Team, 2015) were used.

\section{Results}

A total of 386 specimens of Odonata were collected, with 160 specimens collected in the dry season and 226 in the rainy season. The estimated richness was similar to that observed, with the registration of 19 genera, stabilizing the species accumulation curve with a collection efficiency of $95 \%$. In terms of composition, Perithemis $(\mathrm{n}=44)$ was the most abundant genus, followed by Argia $(\mathrm{n}=19)$ in the dry period (Table S2). Meanwhile, in the rainy season, in addition to Perithemis $(\mathrm{n}=43)$, Hetaerina $(\mathrm{n}=33)$ also had high abundance (Table S3).

The order Odonata and the suborders Anisoptera and Zygoptera showed no differences when compared in terms of richness or abundance between the seasons (Figure 2); therefore not corroborating our hypothesis 1 . However, when we analyze the richness between the suborders (Anisoptera vs Zygoptera) in each season, significant differences were observed (Figure 2C; drought: $t=2.269$, df $=18, p=0.035$; rainy $: t=3.028$, df $=18, p=0.007$ ). 

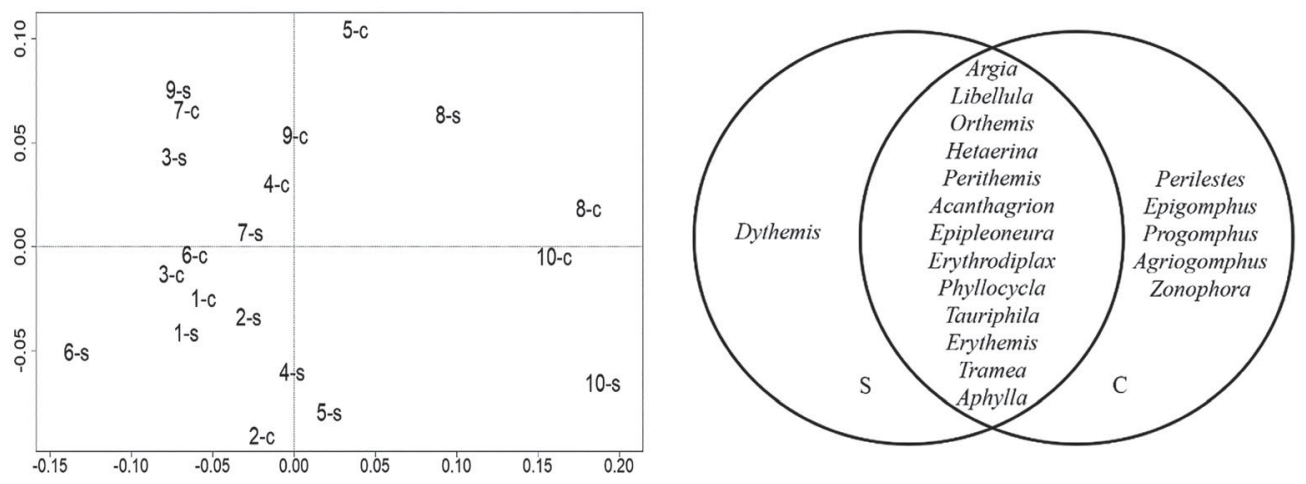

Figure 3. Odonata assembly in the streams sampled in Caxias city, Maranhão (axis 1: 32.01\%; axis 2: 16.30\%). Dry (S) and rainy $(\mathrm{C})$ seasons.
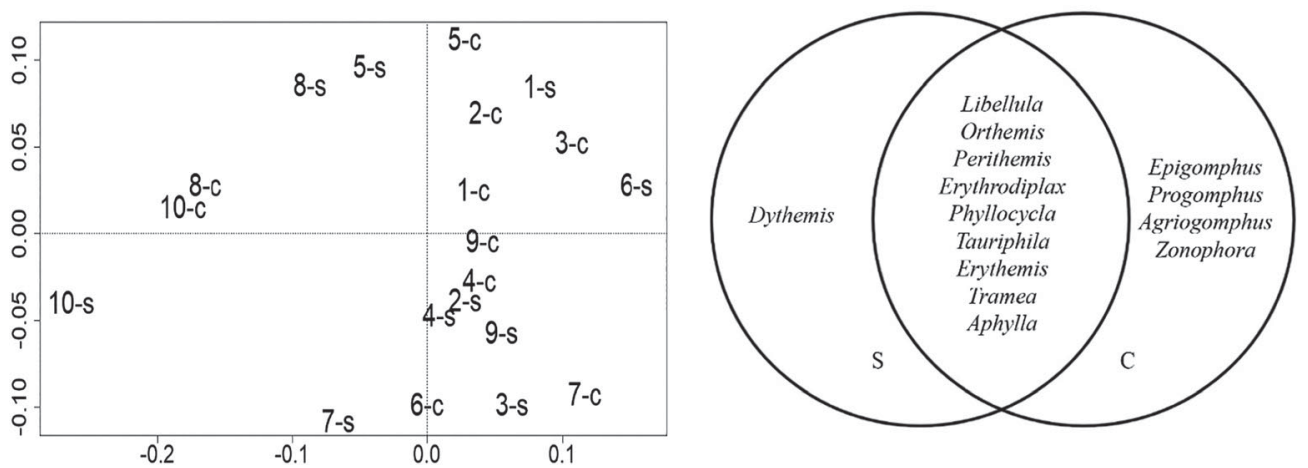

Figure 4. Anisoptera assembly in the streams sampled in Caxias city, Maranhão (axis 1: 28.79\%; axis 2: 20.69\%). Dry (S) and rainy $(\mathrm{C})$ seasons.
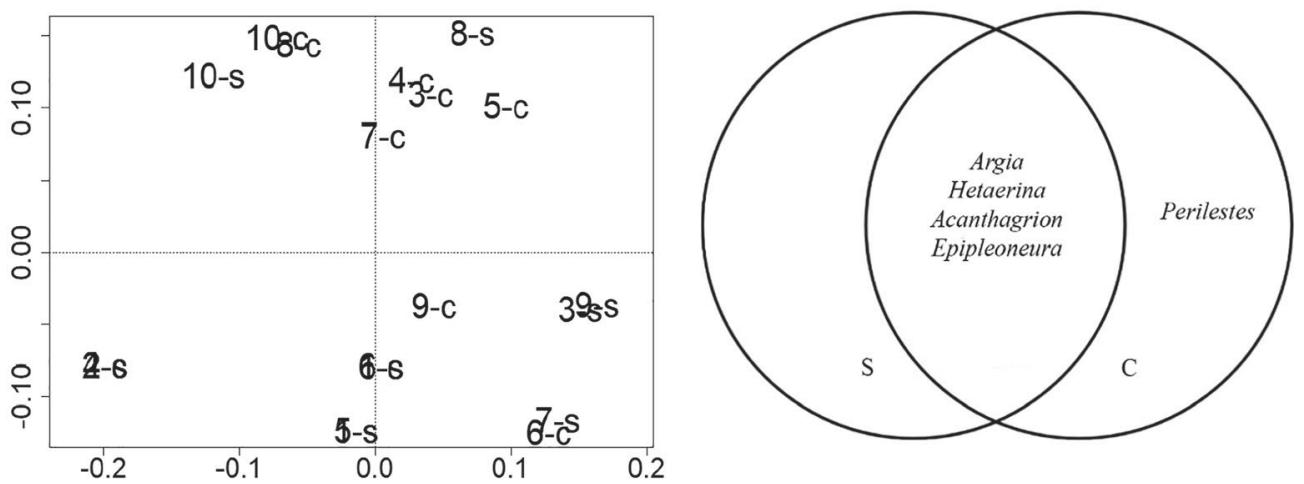

Figure 5. Zygoptera community in the streams sampled in Caxias city, Maranhão (axis 1: 41.72\%; axis 2: 37.30). Dry $(\mathrm{S})$ and rainy $(\mathrm{C})$ seasons.

The composition of Odonata and Anisoptera showed little overlap between seasonal periods (Figures 3, 4 and 6), while Zygoptera showed a high level of congruence between the dry and rainy seasons, with Perilestes being the only genus collected in both seasons (Figures 5 and 6), thus corroborating our hypotheses 2 and 3 . 


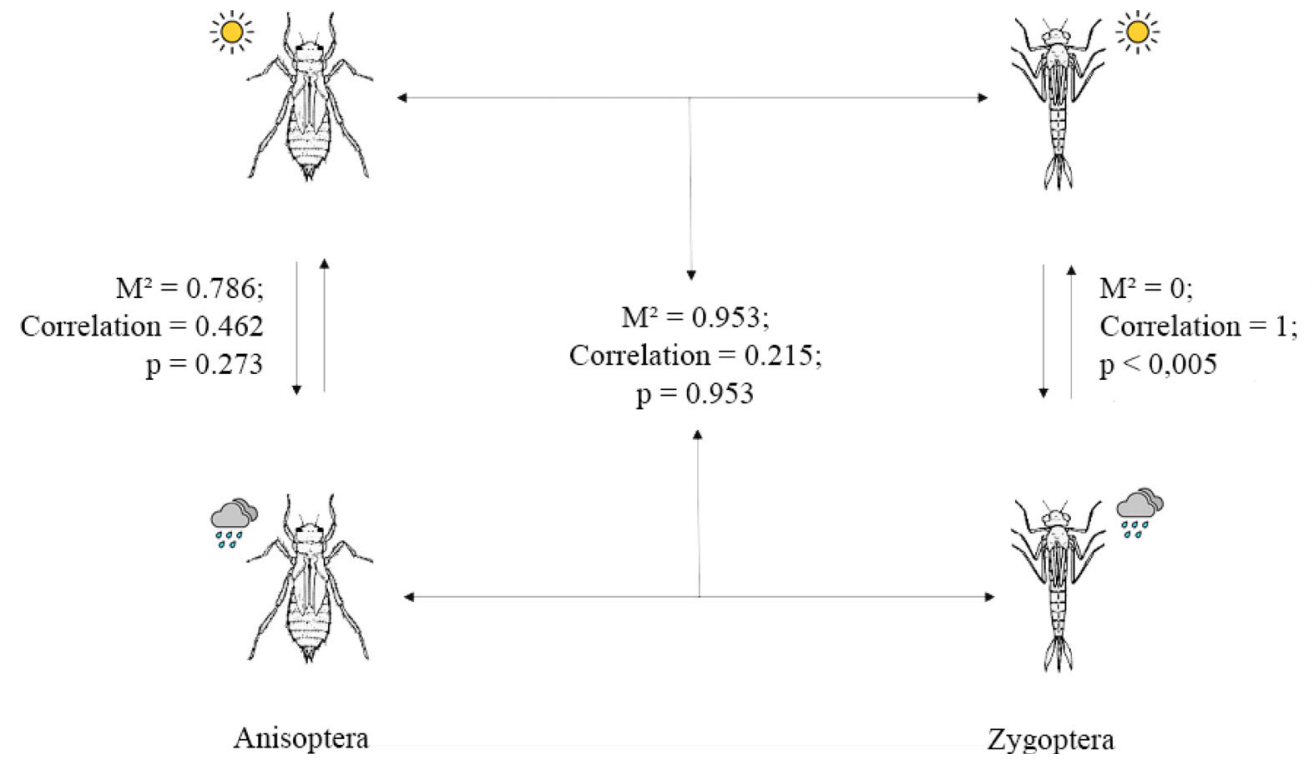

Figure 6. Congruence level in the composition of Odonata larvae (Anisoptera - left; Zygoptera - right) between the seasons of lesser and greater precipitation.

\section{Discussion}

Our results indicate low congruence between the composition of genera of the order Odonata and the suborder Anisoptera between the rainy and dry periods, thus, for studies in savanna biomes that present a high discrepancy between the volumes of precipitation, which has the main tool of inference to community composition, sampling at just one of the stations is not enough to collect all the diversity, losing important information about the real local diversity (Carvalho \& Nessimian, 1998; Dos Santos Bertoncin et al., 2019; García-Roger et al., 2011). This corroborates our hypothesis 2 , stating that the composition of the assemblies is strongly influenced by the processes that occur in the environment, such as the variation in precipitation (Mendes et al., 2019). Meanwhile, metrics such as richness and abundance can be used in just one season, since they did not show significant differences between seasons (Salcedo, 2006; Vilas Boas e Camargo, 2017). However, there was a small increase in the abundance and richness of the order and suborders for the rainy season, that can generate information about adaptation, behavior, survivorship, and consequently potential biodiversity (Salcedo, 2006; Vilas Boas \& Camargo, 2017).

The suborder Anisoptera showed greater richness and abundance than Zygoptera, indicating a greater effect on the general diversity patterns for the order Odonata (Arimoro, Ikomi, Ajuzieogu, \& Nwadukwe, 2011; Mendes et al., 2019). This pattern can be expected, as in the Anisoptera development process, most species have an emergence cycle (changes from larva to adult) two or more times a year (bivoltines or multivoltines), promoting changes in species composition in a short period of time (Corbet, 1999; Reels, 2011). This is different to what is expected for Zygoptera, for which a strong congruence was observed for all metrics evaluated between the dry and rainy seasons. In this taxon, most species are univoltine (with only one emergence cycle) or partially bivoltine (an emergence cycle every two years), remaining in the water for a longer time, allowing sampling both in the period of less precipitation and in the period of greater precipitation (Corbet, 1980; Corbet et al., 2006; Dalzochio, Périco, Renner, \& Sahlén, 2018; Mellal, Zebsa, Bensouilah, Houhamdi, \& Khelifa, 2018). 
Our study indicates that studies with limited financial or time resources, that are to be carried out in areas with strong discrepancies between different seasonal periods, should be sampled in the period of greatest precipitation, because in this season there was the greatest richness of Odonata, with five genera present that did not occur in the dry season, representing $\sim 95 \%$ of the existing biodiversity compared to $\sim 74 \%$ of the biodiversity recorded in the dry season. Meanwhile, in biomonitoring activities, the use of the suborder Zygoptera should be preferred due to the congruence of the taxon between the two stations, to the detriment of Anisoptera. If the focus is on biodiversity, the use of suborders can establish patterns of diversity and adaptation between seasons, in view of the existing ecophysiological differences.

\section{Conclusion}

The composition of the Odonata community (order and suborder Anisoptera) differs between the seasonal periods of areas with savanna biomes. This difference is not observed for the composition of Zygoptera and the other diversity metrics analyzed in the present study. This indicates that for studies that intend to have a broader view of species diversity, the most appropriate metric is the use of species composition.

\section{Acknowledgments}

We thank editor in chief Dr John Abbott and the reviewers for their valuable contributions. We are grateful to the members of the Community Ecology Laboratory (LaECO) for their support in the field and laboratory, to the Federal Institute of Education, Science and Technology of Maranhão for promoting the research scholarship for scientific initiation, as well as to Douglas Moraes Couceiro for his help in preparing of the map.

\section{Funding}

We are grateful to the National Council for Scientific and Technological Development (CNPq) for supporting LJ's research through productivity grants [process no. 307597/2016-4].

\section{Supplemental data}

Supplemental data for this article can be accessed at https://doi.org/10.1080/13887890.2020.1779826.

\section{ORCID}

Lucas Pereira Moura (D) http://orcid.org/0000-0002-8153-9563

Sheyla Regina Marques Couceiro (D) http://orcid.org/0000-0001-8186-4203

Leandro Juen (D) http://orcid.org/0000-0002-6188-4386

Daniel Silas Veras (iD http://orcid.org/0000-0002-3317-7721

\section{References}

Anderson, T. L., \& Semlitsch, R. D. (2016). Top predators and habitat complexity alter an intraguild predation module in pond communities. Journal of Animal Ecology, 85(2), 548-558.

Arimoro, F. O., Ikomi, R. B., Ajuzieogu, I. O., \& Nwadukwe, F. O. (2011). Temporal and spatial variability in macroinvertebrate community structure in relation to environmental variables in Ajijiguan Creek, Niger Delta, Nigeria. African Journal of Aquatic Science, 36(1), 57-66.

Bartels, P., Ask, J., Andersson, A., Karlsson, J., \& Giesler, R. (2018). Allochthonous organic matter supports benthic but not pelagic food webs in shallow coastal ecosystems. Ecosystems, 21(7), 1459-1470. 
Beisel, J. N., Usseglio-Polatera, P., Thomas, S., \& Moreteau, J. C. (1998). Stream community structure in relation to spatial variation: The influence of mesohabitat characteristics. Hydrobiologia, 389(1-3), 73-88.

Carvalho, A. L., \& Nessimian, J. L. (1998). Odonata do estado do Rio de Janeiro, Brasil: hábitats e hábitos das larvas. Ecologia e Insetos Aquáticos: Series Oecologia Basiliensis, 5 3-28.

Corbet, P. S. (1980). Biology of Odonata. Annual Review of Entomology, 25(1), 189-217.

Corbet, P. S. (1999). Dragonflies: Behavior and ecology of Odonata (Ithaca, NY: Comstock Publishing Associates).

Corbet, P. S., Suhling, F., \& Soendgerath, D. (2006). Voltinism of Odonata: A review. International Journal of Odonatology, 9(1), 1-44.

Correia Filho, F. L., Gomes, É. R., Nunes, O. O., \& Lopes Filho, J. B. (2011). Projeto cadastro de fontes de abastecimento por água subterrânea: Estado do Maranhão: Relatório diagnóstico do município de Caxias. Beirut: CPRM.

Costa, J. M., \& Oldrini, B. B. (2005). Diversidade e distribuição dos Odonata (Insecta) no estado do Espírito Santo, Brasil. Publicações Avulsas do Museu Nacional, 107, 1-15.

Costa, C. F., Azevedo, C. A. S., Ferreira, S. S., \& Moura, E. P. S. (2015). Análise microbiológica da água do rio Itapecuru em Caxias, MA, Brasil [Microbiological analysis water at river Itapecuru in Caxias, MA, Brazil]. Revista Interface, 10, 274-283.

Costa, L. D. S. M., Branco, C. C. Z., \& Bispo, P. D. C. (2014). O Papel dos Fatores Ambientais e Espaciais Sobre a Fauna de Ephemeroptera (Insecta) em Riachos de Mata Atlântica. EntomoBrasilis, 7(2), 86-92.

Dalzochio, M. S., Périco, E., Renner, S., \& Sahlén, G. (2018). Effect of tree plantations on the functional composition of Odonata species in the highlands of southern Brazil. Hydrobiologia, 808(1), 283-300.

De Alcântara, E. H. (2004). Caracterização da bacia hidrográfica do rio Itapecuru, Maranhão-Brasil. Caminhos de Geografia, 7(11), 97-113.

De Marco Jr, P., Batista, J. D., \& Cabette, H. S. R. (2015). Community assembly of adult odonates in tropical streams: an ecophysiological hypothesis. PLoS One, 10(4), 17.

Dias-Silva, K., Cabette, H. S. R., Juen, L., \& De Marco, P. (2010). The influence of habitat integrity and physicalchemical water variables on the structure of aquatic and semi-aquatic Heteroptera. Zoologia (Curitiba, Impr.), 27(6), 918-930.

Dos Santos Bertoncin, A. P., Pinha, G. D., Baumgartner, M. T., \& Mormul, R. P. (2019). Extreme drought events can promote homogenization of benthic macroinvertebrate assemblages in a floodplain pond in Brazil. Hydrobiologia, 826, 1-15.

Elosegi, A., \& Pozo, J. (2016). Altered organic matter dynamics in rivers and streams: ecological consequences and management implications. Limnetica, 35(2), 303-322.

Fernandes, R. S., Conceição, G. M. D., Costa, J. M., \& Paula-Zárate, E. L. D. (2010). Samambaias e licófitas do município de Caxias, Maranhão, Brasil. Boletim do Museu Paraense Emílio Goeldi Ciências Naturais, 5(3), 345-356.

Ferreira-Peruquetti, P. S., \& De Marco Jr, P. (2002). Efeito da alteração ambiental sobre comunidades de Odonata em riachos de Mata Atlântica de Minas Gerais, Brasil. Revista Brasileira de Zoologia, 19(2), 317-327.

García-Roger, E. M., Del Mar Sánchez-Montoya, M., Gómez, R., Suárez, M. L., Vidal-Abarca, M. R., Latron, J., \& Prat, N. (2011). Do seasonal changes in habitat features influence aquatic macroinvertebrate assemblages in perennial versus temporary Mediterranean streams? Aquatic Aciences, 73(4), 567-579.

Giam, X., Chen, W., Schriever, T. A., Van Driesche, R., Muneepeerakul, R., Lytle, D. A., \& Olden, J. D. (2017). Hydrology drives seasonal variation in dryland stream macroinvertebrate communities. Aquatic Sciences, 79(3), 705-717.

Hamada, N., Nessimian, J. L., \& Querino, R. B. (2014). Insetos Aquáticos na Amazônia Brasileira. Manaus: Editora do INPA. https://www.alice.cnptia.embrapa.br/handle/doc/1000609

Heino, J., Louhi, P., \& Muotka, T. (2004). Identifying the scales of variability in stream macroinvertebrate abundance, functional composition and assemblage structure. Freshwater Biology, 49(9), 1230-1239.

Instituto Nacional de Meteorologia (INMET). (2020). Redes de estações. Retrieved from http://www.inmet.gov.br/portal/ index.php? $\mathrm{r}=$ home/page\&page $=$ rede_estacoes_auto_graf

Juen, L., Oliveira-Junior, J. M. B., Shimano, Y., Mendes, T. P., \& Cabette, H. S. R. (2014). Composição e riqueza de Odonata (Insecta) em riachos com diferentes níveis de conservação em um ecótone Cerrado-Floresta Amazônica. Acta Amazonica, 44(2), 175-184.

Leps, M., Tonkin, J. D., Dahm, V., Haase, P., \& Sundermann, A. (2015). Disentangling environmental drivers of benthic invertebrate assemblages: The role of spatial scale and riverscape heterogeneity in a multiple stressor environment. Science of the Total Environment, 536, 546-556.

Marques, G. D. V., \& Del-Claro, K. (2010). Seasonality, abundance and biomass of soil insects in a Cerrado reserve. Brazilian Journal of Zoosciences, 12 (2).

Mellal, M. K., Zebsa, R., Bensouilah, M., Houhamdi, M., \& Khelifa, R. (2018). Aspects of the emergence ecology of the regionally endangered Coenagrion mercuriale (Odonata: Coenagrionidae) in Northeast Algeria. Zoology and Ecology, 28(3), 224-230.

Mendes, T. P., Benone, N. L., \& Juen, L. (2019). To what extent can oil palm plantations in the Amazon support assemblages of Odonata larvae? Insect Conservation and Diversity, 12(5), 448-458.

Mendes, T. P., Cabette, H. S. R., \& Juen, L. (2015). Setting boundaries: Environmental and spatial effects on Odonata larvae distribution (Insecta). Anais da Academia Brasileira de Ciências, 87(1), 239-248.

Mendes, T. P., Oliveira-Junior, J. M. B., Cabette, H. S. R., Batista, J. D., \& Juen, L. (2017). Congruence and the biomonitoring of aquatic ecosystems: are odonate larvae or adults the Most effective for the evaluation of impacts. Neotropical Entomology, 46(6), 631-641. 
Monteiro-Junior, C. S., Couceiro, S. R. M., Hamada, N., \& Juen, L. (2013). Effect of vegetation removal for road building on richness and composition of Odonata communities in Amazonia, Brazil. International Journal of Odonatology, $16,135-144$.

Oliveira, C. M. D., \& Frizzas, M. R. (2008). Insetos de Cerrado: distribuição estacional e abundância. ISSN 1676-918X, $1^{\mathrm{a}}$ Ed. p26.

Oliveira, R. R., Medeiros, D. L., Oliveira, H. C., \& Conceição, G. M. (2018). Briófitas de área sob o domínio fitogeográfico do Cerrado e novas ocorrências para o Maranhão e região Nordeste do Brasil. Iheringia. Série Botânica, 73(2), 191-195.

Oliveira-Junior, J. M. B., Cabette, H. S. R., Silva-Pinto, N., \& Juen, L. (2013). As variações na Comunidade de Odonata (Insecta) em Córregos Podem ser preditas pelo paradoxo do Plâncton? Explicando a Riqueza de Espécies Pela Variabilidade Ambiental. EntomoBrasilis, 6(1), 1-8.

Pereira, T. S., Pio, J. F. G., Calor, A. R., \& Copatti, C. E. (2017). Can the substrate influence the distribution and composition of benthic macroinvertebrates in streams in northeastern Brazil? Limnologica - Ecology and Management of Inland Waters, 63, 27-30.

Pinto, A. P. (2016). A fauna de libélulas da América do Sul: a última fronteira a ser desvendada. Zoologia, 177, 7-9.

Pires, M. M., Siegloch, A. E., Hernández, M. I. M., \& Petrucio, M. M. (2020). Environmental drivers and composition of assemblages of immature odonates (Insecta) in a subtropical island in southern Brazil. Acta Limnologica Brasiliensia, 32, 10.

Pontes, M. L. C., De Lima, A. M. M., Júnior, J. D. A. S., \& De Azevedo Sadeck, C. C. (2017). Dinâmica das áreas de várzea do município de Belém/PA e a influência da precipitação pluviométrica na formação de pontos alagamentos. Caderno de Geografia, 27(49), 285-303.

Purse, B. V., \& Thompson, D. J. (2002). Voltinism and larval growth pattern in Coenagrion mercuriale (Odonata: Coenagrionidae) at its northern range margin. European Journal of Entomology, 99(1), p. 11-18.

R Foundation for Statistical Computing. (2015). R. Development Core Team: R: A language and environment for statistical computing. Vienna: R Foundation for Statistical Computing. ISBN 3-900051-07-0.

Reels, G. T. (2011). Emergence patterns and adult flight season of Anisoptera at a managed wetland site in Hong Kong, southern China. International Journal of Odonatology, 14(1), 33-48.

Reis, C. S., \& Conceição, G. M. (2010). Aspectos florísticos de um fragmento de vegetação, localizado no Município de Caxias, Maranhão, Brasil. Scientia Plena, 6(2), 17.

Rosser, Z. C., \& Pearson, R. G. (2018). Hydrology, hydraulics and scale influence macroinvertebrate responses to disturbance in tropical streams. Journal of Freshwater Ecology, 33(1), 1-17.

Salcedo, A. K. M. (2006). Variação temporal e espacial e importância ecológica de macroinvertebrados aquáticos num córrego periurbano do Distrito Federal. [Doctoral dissertation, Dissertação de mestrado]. Universidade de BrasíliaDF, p. 86. http://www.pgecl.unb.br/images/sampledata/arquivos/dissertacoes/2000a2010/2006/Ana\%20Karina\% 20Moreyra\%20Salcedo.pdf.

Shimano, Y., Cardoso, M., \& Juen, L. (2018). Ecological studies of mayflies (Insecta, Ephemeroptera): Can sampling effort be reduced without losing essential taxonomic and ecological information? Acta Amazonica, 48, $137-145$.

Souza, H. M. D. L. (2010). Influência da integridade ambiental sobre a comunidade de baetidae (insecta: ephemeroptera) em córregos do cerrado matogrossense, [Doctoral dissertation, Universidade do Estado de Mato Grosso]. Brasil: Universidade do Estado de Mato Grosso.

Valente-Neto, F., de Oliveira Roque, F., Rodrigues, M. E., Juen, L., \& Swan, C. M. (2016). Toward a practical use of Neotropical odonates as bioindicators: Testing congruence across taxonomic resolution and life stages. Ecological Indicators, 61, 952-959.

Vaz, A. A., Vaz, A. A., Pelizari, G. P., Biagioni, R. C., \& Smith, W. S. (2017). A biota aquática em um riacho tropical e suas relações com fatores ambientais. Biodiversidade Brasileira, 7(1), 55-68.

Veras, D. S., Castro, E. R., Lustosa, G. S., Azevêdo, C. A. S, \& Juen, L. (2019). Evaluating the habitat integrity index as a potential surrogate for monitoring the water quality of streams in the cerrado-caatinga ecotone in northern Brazil. Environmental Monitoring and Assessment, 191(9), 562. https://doi.org/10.1007/s10661-019-7667-x

Veras, D. S., Medeiros-França, L. C., \& Azêvedo, C. A. S. (2018). Heterogeneidade espaço-temporal ambiental de igarapés em um ecótono Cerrado-Caatinga. Acta Brasiliensis, 2(3), 84-88.

Vilas Boas, A. H., \& Camargo, F. D. V. (2017). Avaliação rápida da qualidade da água utilizando invertebrados bentônicos, através dos índices bióticos BMWP' e ASPT no ribeirão São Bernardo, Piranguçu, sul de Minas Gerais. CES Revista, 1(1), 7-25.

Yokoyama, E., Paciencia, G. D. P., Bispo, P. D. C., Oliveira, L. G., \& Bispo, P. D. C. (2012). A sazonalidade ambiental afeta a composição faunística de Ephemeroptera e Trichoptera em um riacho de Cerrado do Sudeste do Brasil? Ambiência - Revista do Setor de Ciências Agrárias e Ambientais, 8(1), 73-84. 